UCRL-ID-119842

\title{
Geothermal Areas as Analogues to Chemical Processes in the Near-Field and Altered Zone of the Potential Yucca Mountain, Nevada Repository
}

\author{
Carol J. Bruton
}

William E. Glassley

Annemarie Meike

February 1995

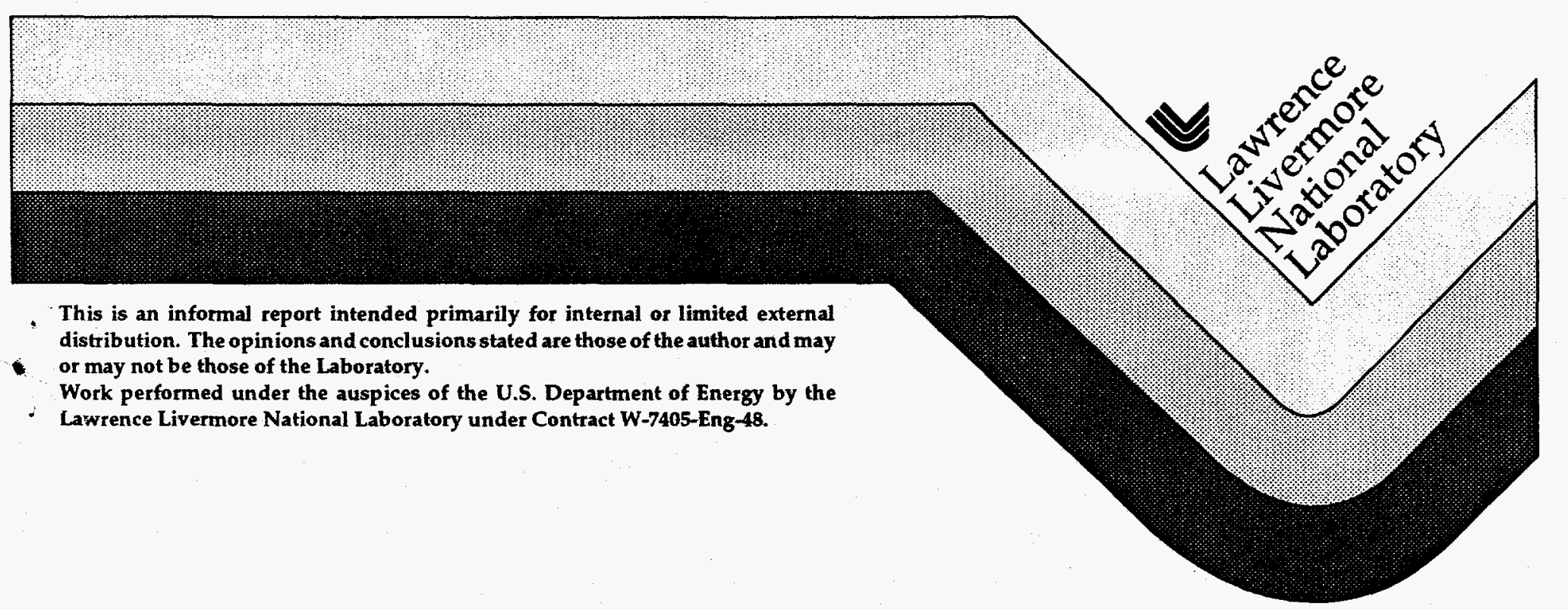




\section{DISCLAIMER}

This document was prepared as an account of work sponsored by an agency of the United States Covernment. Neither the United States Government nor the University of California nor any of their employees, makes any warranty, express or implied, or assumes any legal liability or responsibility for the arcuracy, completeness, or usefulness of any information, apparatus, product, or process disclosed, or represents that its use would not infringe privately owned rights. Reference herein to any specific commercial product, process, or service by trade name, trademark, manufacturer, or otherwise, does not necessarily constitute or imply its endorsement, recommendation, or favoring by the United States Government or the University of California. The views and opinions of authors expressed herein do not necessarily state or reflect those of the United States Government or the University of California, and shall not be used for advertising or product endorsement purposes.

This report has been reproduced directly from the best available copy.

Available to DOE and DOE contractors from the Office of Scientific and Technical Information

P.O. Box 62, Oak Ridge, TN 37831

Prices available from (615) 576-8401, FTS 626-8401

Available to the public from the

National Technical Information Service

U.S. Department of Commerce

5285 Port Royal Rd.,

Springfield, VA 22161 


\section{DISCLAIMER}

Portions of this document may be illegible in electronic image products. Images are produced from the best available original document. 
Geothermal areas as analogues to chemical processes in the near-field and altered zone of the potential Yucca Mountain, Nevada repository

Carol J. Bruton, William E. Glassley and Annemarie Meike

\begin{abstract}
The need to bound system performance of the potential Yucca Mountain repository for thousands of years after emplacement of high-level nuclear waste requires the use of computer codes such as EQ3/6 (Wolery et al., 1990). The use of such codes to produce reliable bounds over such long time periods must be tested using long-lived natural and historical systems as analogues. For our purposes, an analogue is a system where a process significant to the evolution or performance of the potential repository can be studied.
\end{abstract}

Buscheck and Nitao (1993) and Glassley et al. (1993) described some of the hydrothermal and chemical processes anticipated under various repository scenarios. The processes include evaporation, boiling, condensation, one- and two-phase fluid flow, mineral precipitation and dissolution, ion exchange and surface complexation. Materials introduced during repository construction (Meike, 1994) as well as the rocks hosting the repository will be affected by these processes. We catalogued and critiqued a large number of potential analogue sites where the impact of these processes could be observed in systems with similarities to Yucca Mountain.

The geothermal systems of the Taupo Volcanic Zone (TVZ) in New Zealand were selected as the site most amenable to study. The rocks of the TVZ are silicic volcanics that are similar in composition to Yucca Mountain. The area has been subjected to temperatures of 25 to $300^{\circ} \mathrm{C}$ which have produced a variety of secondary minerals similar to those anticipated at Yucca Mountain. The availability of rocks, fluids and fabricated materials for sampling is excellent because of widespread exploitation of the systems for geothermal power. A wide variety of chemical phenomena and processes such as those listed above occur in a variety of chemical environments. Manufactured materials have been used in drilling and geothermal power production, which affords us the opportunity to study rock-water-material interactions.

A collaborative relationship with the Institute of Geological and Nuclear Sciences in Wairakei, New Zealand has been established to assist us in our studies. Current work has focused on testing the ability of the EQ3/6 code and thermodynamic data base to describe mineral-fluid relations at elevated temperatures. We are starting long-term dissolution/corrosion tests of rocks, minerals and manufactured materials in natural thermal features in order to compare laboratory rates with field-derived rates. Available field data on rates of silica precipitation from heated fluids have been analyzed and compared to laboratory rates. New sets of precipitation experiments are being planned. The microbially influenced degradation of concrete in the Broadlands-Ohaaki geothermal field is being characterized. We will continue to work on these projects in FY1996 and expand to include the study of naturally occurring uranium and thorium series radionuclides, as a prelude to studying radionuclide migration in heated silicic volcanic rocks. 


\section{Introduction}

Natural and historical analogues are being used to test or "validate" geochemical modeling codes that simulate the chemical response of Yucca Mountain to the emplacement of high-level nuclear waste. Long-term storage of nuclear waste in a geologic repository may subject the surrounding environment to temperature fluctuations, variations in fluid flow, chemical changes, ionizing radiation, radionuclide migration and other phenomena. Federal regulations require that we predict the impact of these phenomena on system performance for up to 10,000 years (NRC, 1988; EPA, 1985). Owing to our inability to reproduce the chemical impact of these complex phenomena over such time periods in the laboratory, we look to natural analogues as a means of testing our modeling capabilities (e.g. EQ3/6; Wolery et al., 1990). We then use this information to help us bound the chemical evolution of the near-field environment and altered zone through time.

Analysis of the post-closure near-field environment and phenomena in the potential Yucca Mountain repository (Wilder, 1993) shows the possibility for a temperature peak near $200^{\circ} \mathrm{C}$, elevated temperatures for hundreds to thousands of years, and variable relative humidity near the waste. These conditions are conducive to processes.such as evaporation, boiling, condensation, one- and two-phase fluid flow, mineral precipitation and dissolution, ion exchange and surface complexation. Many of these physical and chemical phenomena are occurring presently in the hydrothermal systems developed in the silicic volcanic rocks of the Taupo Volcanic Zone, North Island, New Zealand. Heated fluids have been reacting with silicic rocks, volcanic glasses and manufactured materials in the geothermal systems in New Zealand for long periods of time. We are therefore using the New Zealand systems to critically test the EQ3/6 geochemical modeling codes, and to catalog the impact of potential repository processes on silicic volcanic rocks and fluid chemistry.

The purpose of this paper is to discuss our choice of the hydrothermal systems in New Zealand as our initial analogue site. We will first outline the criteria we used to identify potential analogues to anticipated Yucca Mountain processes. We will then describe how and why we chose the hydrothermal systems in the Taupo Volcanic Zone, North Island, New Zealand as opposed to other systems. Finally, ongoing and planned projects based in New Zealand will be outlined.

\section{What are natural and historical analogues, and why are they necessary?}

For our purposes, a natural or historical analogue is a system where a process significant to the evolution or performance of the potential repository can be studied (see also Chapman et al., 1992). The choice of an analogue site(s) depends on the degree to which conditions or characteristics of the system overlap those expected for the repository. An analogue must contain opportunities to test specific aspects of the geochemical modeling codes, and/or serve as an example of the impact of a repository-induced process on a natural system.

For example, in the case of studies that determine bounds for the chemistry of water that might contact waste containers, natural analogues would include geological systems that provide information on the:

- rates at which chemical interactions occur

- influence of flow rates on water chemistry 
- effects of manufactured materials, such as concrete, on water chemistry, total water budget and colloid formation

- impact of mineral dissolution or secondary mineral formation on fluid flow and heat transfer

Natural and historical analogues are necessary because:

- laboratory experiments can last only a few years, at most, while repository performance must be assured for thousands of years

- slow but significant reactions are only observed over the long term

- the heterogeneity and complexity of natural systems can not be adequately reproduced in a laboratory experiment

- computer simulations of repository processes must be evaluated to see if they reproduce essential features of the observed behavior of natural systems

Federal regulations require that we predict system performance for thousands of years. Evaluation of the performance of a nuclear waste repository requires that numerous parameters be evaluated over a broad range of conditions using computer codes. Many of these parameters must be precisely bounded in order to meet performance goals described in the Site Characterization Plan (DOE, 1988; see Table 1). The abilities of modeling codes to accurately establish whether

TABLE 1. Water quality performance parameters and goals for Issue 1.4 (containment by waste package): quality of liquid water that can contact the container (from DOE, 1988; Table 8.3.5.9-2).

\begin{tabular}{|l|l|l|}
\hline Performance parameter & Tentative goals & Needed confidence \\
\hline $\mathrm{pH}$ & 5.5 to 9 & High \\
\hline $\mathrm{Cl}^{-}$ & $<20 \mathrm{ppm}$ & High \\
\hline $\mathrm{F}$ & $<6 \mathrm{ppm}$ & High \\
\hline $\mathrm{NO}_{3}{ }^{-}$ & $<15 \mathrm{ppm}$ & High \\
\hline $\mathrm{SO}_{4}{ }^{2-}$ & $<50 \mathrm{ppm}$ & High \\
\hline $\mathrm{CO}_{3}{ }^{2-}, \mathrm{HCO}_{3}{ }^{-}$ & $<200 \mathrm{ppm}$ & Medium \\
\hline $\mathrm{Total}_{\text {anions }}$ & $<220 \mathrm{ppm}$ & Medium \\
\hline $\mathrm{Organics}^{-}$ & to be decided & to be decided \\
\hline $\mathrm{Colloids}$ & to be decided & to be decided \\
\hline $\mathrm{O}_{2}$ & $0.1 \mathrm{to} 0.8 \mathrm{ppm}$ & High \\
\hline $\mathrm{NH}$ & & High \\
\hline $\mathrm{Si}^{4+}$ & $<1 \mathrm{ppm}$ & High \\
\hline $\mathrm{Na}{ }^{+}$ & $>20 \mathrm{ppm}$ & High \\
\hline $\mathrm{K}^{+}$ & $<100 \mathrm{ppm}$ & High \\
\hline $\mathrm{Na}$ Ca & $<50 \mathrm{ppm}$ & High \\
\hline Total heavy metals & $>1$ & High \\
\hline Total other cations & $<2 \mathrm{ppm}$ & High \\
\hline & $<50 \mathrm{ppm}$ & \\
\hline
\end{tabular}

these conditions are met must be demonstrated using complex natural systems in which the processes of interest are or have been operative. 
The extent to which the EQ3/6 computer codes accurately simulate processes relevant to a nuclear waste repository is being tested by comparing computer simulations of fluid-solid interactions with field data from the New Zealand geothermal systems in a set of field-based modeling exercises. The degree of match between modeling results and observed reactions will help us to identify whether: 1) our mathematical descriptions of the processes are adequate; 2) we have correctly identified the controlling processes; 3 ) we have used appropriate data and input parameters; and 4) the degree to which the conceptual model of the system must be further developed before meaningful results are achieved. Modeling exercises in New Zealand to date have been used to identify appropriate thermodynamic data for minerals, develop protocol for the use of geochemical submodels in specific environments, and select appropriate input parameters for subprocess models (Bruton et al., 1994a).

During the course of this project, developments and/or refinements required in EQ3/6 and its thermodynamic data base will be identified. This information can then be used to constructively guide and prioritize future code development. The project will point to additional data needs from site characterization that would permit more realistic performance assessment calculations. Information from this project will be directed to characterization of the near-field environment and altered zone.

Natural and historical analogues provide the ultimate tests of our ability to set bounds on the long-term evolution and performance of a high level nuclear waste repository. 


\section{Criteria used for selection of first analogue site}

In searching for our first natural analogue site, we catalogued important processes, interactions and phenomena that have been hypothesized to occur in the potential Yucca Mountain repository (e.g. Buscheck and Nitao, 1993; Wilder, 1993; Glassley et al., 1993). Examples of phenomena considered, and their relevance to the Yucca Mountain project, are listed in Table 2.

TABLE 2. Phenomena hypothesized to occur in the potential Yucca Mountain repository

\begin{tabular}{|c|c|}
\hline Phenomena/process & Yucca Mt. relevance \\
\hline Single phase fluid flow and associated alteration & Mineral reactions/fluid chemistry in Regime $A^{a}$ \\
\hline Two phase fluid flow and associated alteration & Mineral reactions/fluid chemistry in Regime $\mathrm{B}^{\mathrm{b}}$ \\
\hline Boiling and condensation- "condensate umbrella" & Mineral reactions/fluid chemistry in Regime $\mathrm{B}^{\mathrm{b}}$ \\
\hline Variable relative humidity at $\mathrm{T}<$ boiling & Mineral reactions/fluid chemistry in Regime $A^{a}$ \\
\hline Variable relative humidity at $\mathrm{T}>$ boiling & Mineral reactions/fluid chemistry in Regime $C^{\mathfrak{C}}$ \\
\hline Retrograde mineral reactions & Mineral reactions/fluid chemistry in Regime $D^{d}$ \\
\hline Mineral precipitation during fracture flow & Changes in porosity, permeability, exchange capacity \\
\hline Matrix and fracture alteration and their interrelation & Drying-out; effect of fracture flow on matrix \\
\hline Microbial degradation of fabricated materials & Microbial impacts on degradation rates/products \\
\hline De/rehydration of solid phases (e.g. cements) & Additions to total water budget \\
\hline Decomposition of organic compounds & Effect on rxn rates, fluid chemistry, colloid formation \\
\hline Precipitation/dissolution along chemical gradient & Colloid formation and sorption \\
\hline \multicolumn{2}{|c|}{$\begin{array}{l}\text { As defined by Glassley (1993), areas where T<T(boiling) and in-situ pore water is heated and evaporating, } \\
\text { resulting in elevated water vapor pressures (i.e. relative humidity). See text. }\end{array}$} \\
\hline \multicolumn{2}{|c|}{$\begin{array}{l}\text { b As defined by Glassley (1993), areas where } T=T \text { (boiling), resulting in boiling and steam movement through } \\
\text { fractures, and condensation at edge of boiling zone. See text. }\end{array}$} \\
\hline \multicolumn{2}{|c|}{${ }^{c}$ As defined by Glassley (1993), areas where $\mathrm{T}>\mathrm{T}$ (boiling) and relative humidity is variable and low. See text. } \\
\hline \multicolumn{2}{|c|}{$\begin{array}{l}\text { dAs defined by Glassley (1993), rock first heated to elevated temperatures and now returning to pre-emplace- } \\
\text { ment conditions of temperature, relative humidity as modified by rock alteration that has occurred. See text. }\end{array}$} \\
\hline
\end{tabular}


An ideal site would have the conditions and characteristics listed in Table 3 that overlap those

TABLE 3. Characteristics of appropriate analogue sites

\begin{tabular}{|l|}
\hline Temperatures covering range 25 to $300^{\circ} \mathrm{C}$-spanning anticipated conditions in near-field/altered zone \\
\hline Wide range of phenomena and features available for study \\
\hline Range of porosity, permeability, fracture characteristics similar to Yucca Mountain \\
\hline Range of water chemistries that bound those that may exist about the repository \\
\hline $\begin{array}{l}\text { Suite of secondary minerals expected to form at Yucca Mountain (e.g. zeolites, clays, carbonates, silica } \\
\text { polymorphs, oxides) }\end{array}$ \\
\hline Presence of manufactured materials (e.g. cements, metals) for study of rock-water-materials interactions \\
\hline Processes operative for time periods spanning those of the repository (1-10,000 years) \\
\hline Immediate access to data with minimal expenditure of funds \\
\hline System is active so that processes of interest can be monitored \\
\hline Recent system perturbations to determine response rate and mechanisms \\
\hline Recorded history adequate to document changes in system \\
\hline Drill holes, cores and production holes accessible and widespread \\
\hline Ability to sample fluids representative of subsurface conditions \\
\hline Water-saturated and unsaturated environments (i.e. regions with different relative humidities) \\
\hline Existence of high-temperature mineral assemblages subjected to lower temperatures \\
\hline Fracture and matrix reactions for comparison, interrelations \\
\hline Research/analytical facilities for rapid analysis of fluid and rock samples near study site \\
\hline
\end{tabular}

anticipated in the repository. The types of information required to constrain our chemical models and our conceptual description of the systems upon which the models are based are listed in Table 4. This information should be already known or readily acquired for the ideal study site.

TABLE 4. Information required of appropriate analogue sites

\begin{tabular}{|l|}
\hline Temperature, pressure (fluid and lithostatic) \\
\hline Fluid chemistry \\
\hline Flow regime characterized through time \\
\hline Geologic history reconstruction (e.g. position of water table through time, fluid flow pathways) \\
\hline Secondary mineral assemblages documented through space and time \\
\hline Mineral chemistry \\
\hline Fluid inclusion data \\
\hline Isotopic data \\
\hline Ability to acquire additional field data (e.g. water chemistry, rock/manufactured materials samples) \\
\hline Ability to assess relative significance of biotic and abiotic paths of chemical reactions \\
\hline Ability to assess need for a microbial module in EQ3/6 to model degradation of manufactured materials \\
\hline Ability to assess capability of EQ3/6 to model organic degradation \\
\hline
\end{tabular}

We surveyed potential geothermal systems in the U.S. and throughout the world using literature searches and professional contacts. Our initial searches were concentrated on those areas 
which contained zeolites, whose stability is of great concern to Yucca Mountain because of their impact on ion exchange capacity along potential pathways of radionuclide migration, and changes in hydraulic parameters related to their dissolution and precipitation. Table 5 lists some of the

TABLE 5.

\begin{tabular}{|l|}
\hline Partial list of geologic locales investigated \\
\hline The Geysers, CA \\
\hline Long Valley Caldera, CA \\
\hline Newberry Volcano, central OR \\
\hline Valles Caldera, NM \\
\hline Yellowstone, WY \\
\hline Iceland geothermal systems \\
\hline Japan - mostly Miocene pyroclastic and volcanogenic sedimentary rocks (e.g. oil fields penetrating Green \\
Tuff; Yamakata district; Onikobe and Katayama systems; Yugawara Hot Spring; Tanzawa Mts.) \\
\hline Larderello and other locales, Italy \\
\hline Taupo Volcanic Zone, North Island, New Zealand (e.g. Wairakei, Ohaaki-Broadlands) \\
\hline Cerro Prieto, Mexico \\
\hline
\end{tabular}

geologic areas that were surveyed. The geothermal systems were then evaluated on the basis of criteria listed above. Their accessibility and development, extent and breadth of available data, degree of characterization and presence of desired characteristics, and the potential to acquire additional data as needed, were important factors in our decision. It was also necessary to be able to couple prediction of rock alteration and changes in fluid chemistry with studies of interactions with manufactured materials. We searched for potential collaborative contacts that would facilitate and strengthen our project, while minimizing the time and cost of achieving our objectives, by contacting researchers known to be working in these areas (e.g. from U.S. Geological Survey and Institute of Geological and Nuclear Sciences, New Zealand).

We initially narrowed the search by focusing on silicic or rhyolitic tuffs because of their similarity in rock type, emplacement mode, chemistry and mineralogy to Yucca Mountain. This eliminated sites such as the geothermal systems in Iceland which are dominated by basalts, The Geysers, CA which is strongly influenced by graywackes and ultramafic rocks, and Cerro Prieto which contains sandstones, siltstones and shales. We also ruled out the study of fossil systems such as the Vieja Group in Texas because of difficulty in reconstructing past history and conditions, and the inability to obtain water samples indicative of conditions when the system was active. No manufactured materials studies would be possible in fossil systems, as well.

We decided to focus initially on fluid-dominated systems rather than vapor-dominated ones, such as The Geysers and Larderello, Italy. This decision, discussed in more detail later in this paper, was based on the fact that the mechanistic process models upon which EQ3/6 operates are rigorously appropriate to fluid-dominated systems. Because the mechanisms of fluid-rock interaction in unsaturated systems are not well known, we concluded that we should first develop a "calibrated" modeling protocol and confidence in our models' ability to mimic saturated systems. We plan to use our experience in saturated systems as a baseline from which to develop a strategy to 
simulate unsaturated conditions. We will then be better able to identify the impact of saturation state when we investigate fluid-rock interactions in vapor-dominated systems.

Some of the fields we surveyed (e.g. in Japan, Italy, Yellowstone, U.S.) were excluded because of problems with accessibility and acquisition of additional rock and fluid samples and data as needed. In Yellowstone National Park, in particular, collection of representative downhole fluid samples would require confronting a complex bureaucratic structure that was unlikely to grant permission to sample the wells on a regular basis. A lack of geothermal development would also limit studies of manufactured materials-fluid-mineral interactions. At the time of the survey, there also existed some unresolved questions about the temperature history of Yellowstone owing to the impact of glacial periods. Although not chosen for the present study, Yellowstone would be an excellent analogue for a number of code tests and observations related to potential Yucca Mountain scenarios, and should be pursued at some point in the future.

Other systems were omitted because of a lack of available data, or the presence of a limited number of processes of interest. For example, the Long Valley Caldera was not chosen because limited data exists on hydrothermal minerals in the system (Meijer, unpublished ms). Meijer (unpublished $\mathrm{ms}$ ) also pointed out that zeolites did not occur in the Long Valley Caldera system. Because of the importance of zeolites and their chemistry and stability to the Yucca Mountain project, the Long Valley Caldera was not selected as our primary study site. The Newberry Volcano was omitted for a lack of required data.

The Valles Caldera was not chosen because much less information about rock-water interaction, including rock and fluid samples, were available than in the Taupo Volcanic Zone of New Zealand. The number and variety of thermal features available for study at New Zealand are much greater than at Valles Caldera. Rock-water interaction scenarios in a greater number of chemical and physical settings were also available in the TVZ. Geothermal development is more extensive in New Zealand as well.

It became clear that producing geothermal systems were prime candidates for study because of the use of manufactured materials in them, the availability of fluid samples, detailed knowledge about system hydrology, the wide variety of features available for study in a single field, and a wide range of fluid chemistries and physical conditions in different parts of the system. Given the above criteria and the results of our survey, we selected the Taupo Volcanic Zone (TVZ) in the North Island, New Zealand, as an ideal test site. New Zealand has accessible, well-studied geothermal systems that can be used as field-based exercises with limited expenditure. The close proximity of the Wairakei laboratory of the Institute of Geological and Nuclear Sciences is an added advantage.

\section{Geothermal systems in the Taupo Volcanic Zone, New Zealand}

\section{Geologic setting}

The Taupo Volcanic Zone (Figure 1) occupies a northeast-trending depression about 30-80 $\mathrm{km}$ wide and $250 \mathrm{~km}$ long in the North Island of New Zealand. Basin-fill is comprised of thousands of feet of silicic volcanic lavas and pyroclastics generated from a set of rhyolite caldera volcanoes. The calderas are similar in size to the Crater Flat, Timber Mountain and Silent Canyon 


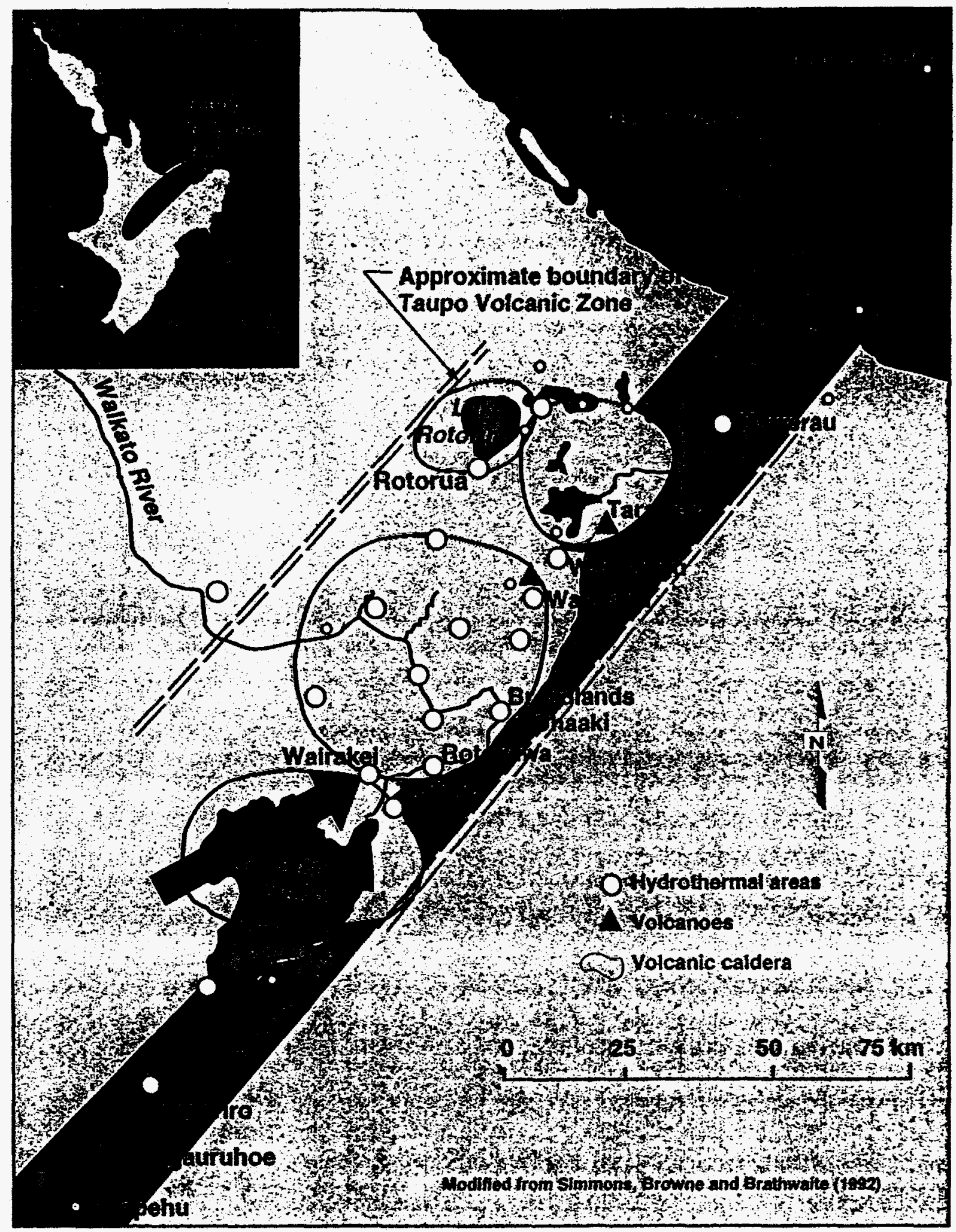

ES9/22/93CBag-ora

Figure 1. Location map of the Taupo Volcanic Zone, North Island, New Zealand with selected hydrothermal areas and volcanic features. Shaded strip represents the andesitic arc. Adapted from Simmons, Browne and Brathwaite (1992). 
calderas and others in the vicinity of Yucca Mountain. The TVZ is anchored at both ends by andesitic volcanoes - White Island to the north, the Tongariro andesitic volcanic complex to the south. The eastern margin of the TVZ is defined by a line of active andesite and dacite volcanoes (Simmons, Browne and Brathwaite, 1992).

The TVZ is a back-arc basin that is spreading at a rate of about $12 \mathrm{~mm} / \mathrm{yr}$. The westward-dipping Pacific Plate is being subducted into the Hikurangi Trough subduction zone, which extends northward to the Tonga-Kermadec arc (Figure 2) (Simmons, Browne and Brathwaite, 1992). A somewhat similar situation occurred in the Western U.S. during the Eocene when a subduction zone operated off the west coast of the U.S., and volcanic activity in the Yucca Mountain area was related to crustal extension in the Basin and Range province.

A cross-section of the Wairakei geothermal field is shown in Figure 3. Characteristics of the Wairakei site are generally similar to other geothermal fields in the TVZ. Both Yucca Mountain and the geothermal fields in the TVZ are dominated by the same silicic rock types cut by normal faulting. The silicic volcanic rocks $\left(70-75 \% \mathrm{SiO}_{2}\right)$ of the TVZ are compositionally and mineralogically similar to those at Yucca Mountain. Mesozoic graywacke and argillite underlie the TVZ volcanics.

The oldest volcanic rocks are about $1.6 \mathrm{ma}$. However, some of the volcanism in the TVZ is quite recent. For example, there was a violent eruption at Taupo in $186 \mathrm{AD}$, and one about 1100 years ago at Okataina. The modern hydrothermal systems have been active for periods of time ranging from 10,000 years to 300,000 years (Simmons, Browne and Brathwaite, 1992).

The Nuclear Regulatory Commission (NRC, 1988) and Environmental Protection Agency (EPA, 1985) have issued regulations requiring performance evaluation of a potential repository for 10,000 and 100,000 years, respectively, after closure (Figure 4). The time scales spanned by the TVZ systems are thus appropriate for evaluating system response over extended time periods. In addition, historical events such as the eruptions at Taupo and Mt. Tarawera give us starting dates for processes that may still be ongoing today. For example, some of the volcanic glasses from the Mt. Tarawera eruption have been in contact with lake waters of nearly constant composition over 900 years since the eruption. We can examine the 900 year degradation of the glasses in that environment to add to our understanding of glass degradation rates and mechanisms.

\section{Hydrothermal activity and geothermal development}

High heat flow, an abundant water supply and northeast-trending normal faulting through the TVZ volcanic pile have produced an abundant source of geothermal energy and a wide variety of surface thermal features such as fumaroles, geysers, mud pots, "steaming ground", and hot springs. About 20 known hydrothermal systems, defined largely on distinct water upflow regions, span the TVZ. There has been extensive drilling of TVZ thermal areas as part of geothermal exploration and production programs since the 1950's. A large number of wells translates to greater availability of rock and fluid samples over a wide range of conditions, and access to manufactured materials in many of these environments. For example, over 100 wells have been drilled at Wairakei, about 20 at Kawerau and over 50 at Broadlands/Ohaaki. Cores and water samples are available for study from many of these wells. Geothermal energy production at Wairakei started 


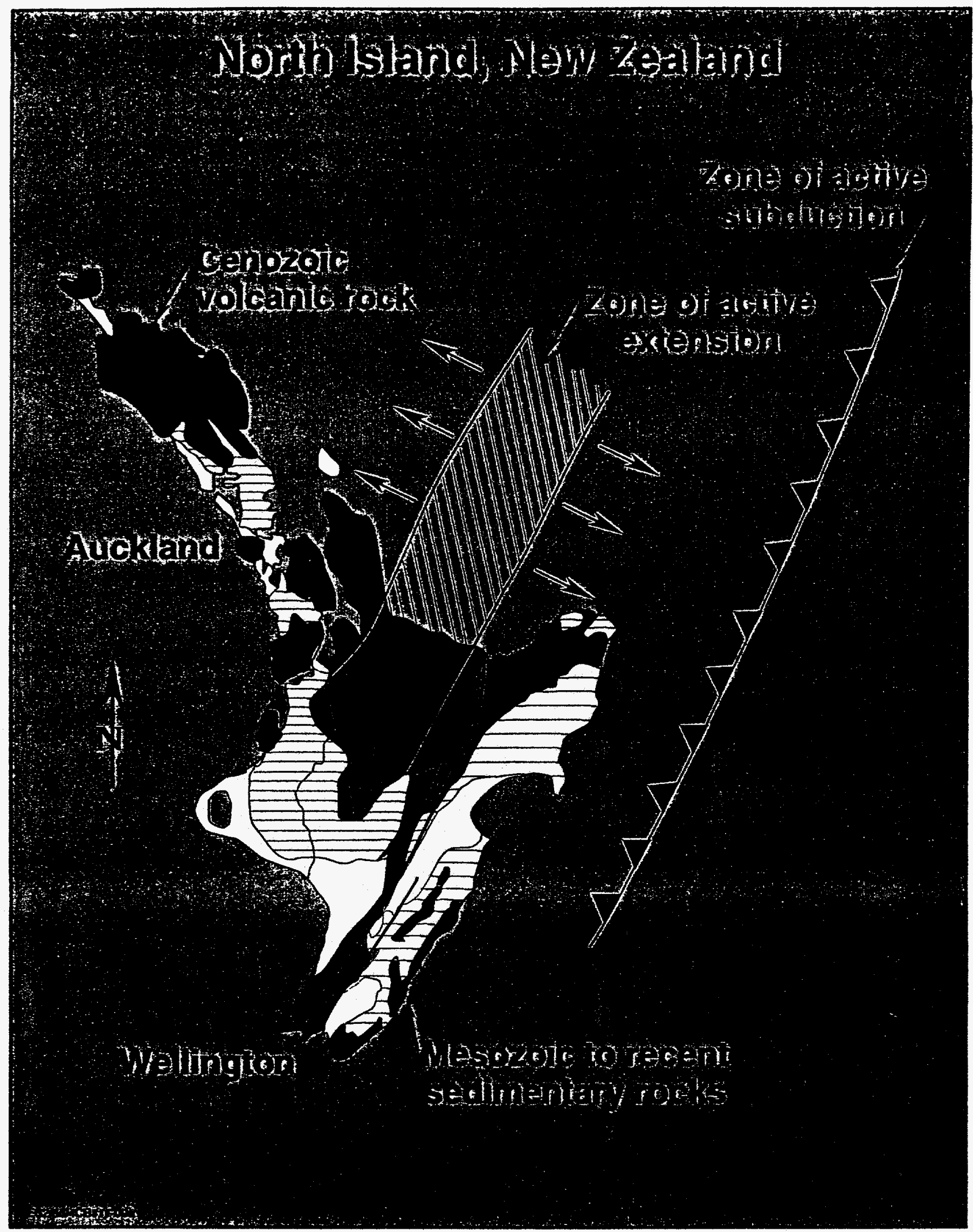

Figure 2. Schematic drawing of plate tectonic setting of the North Island, New Zealand (after Simmons, Browne and Brathwaite, 1992). Not to scale. 
West

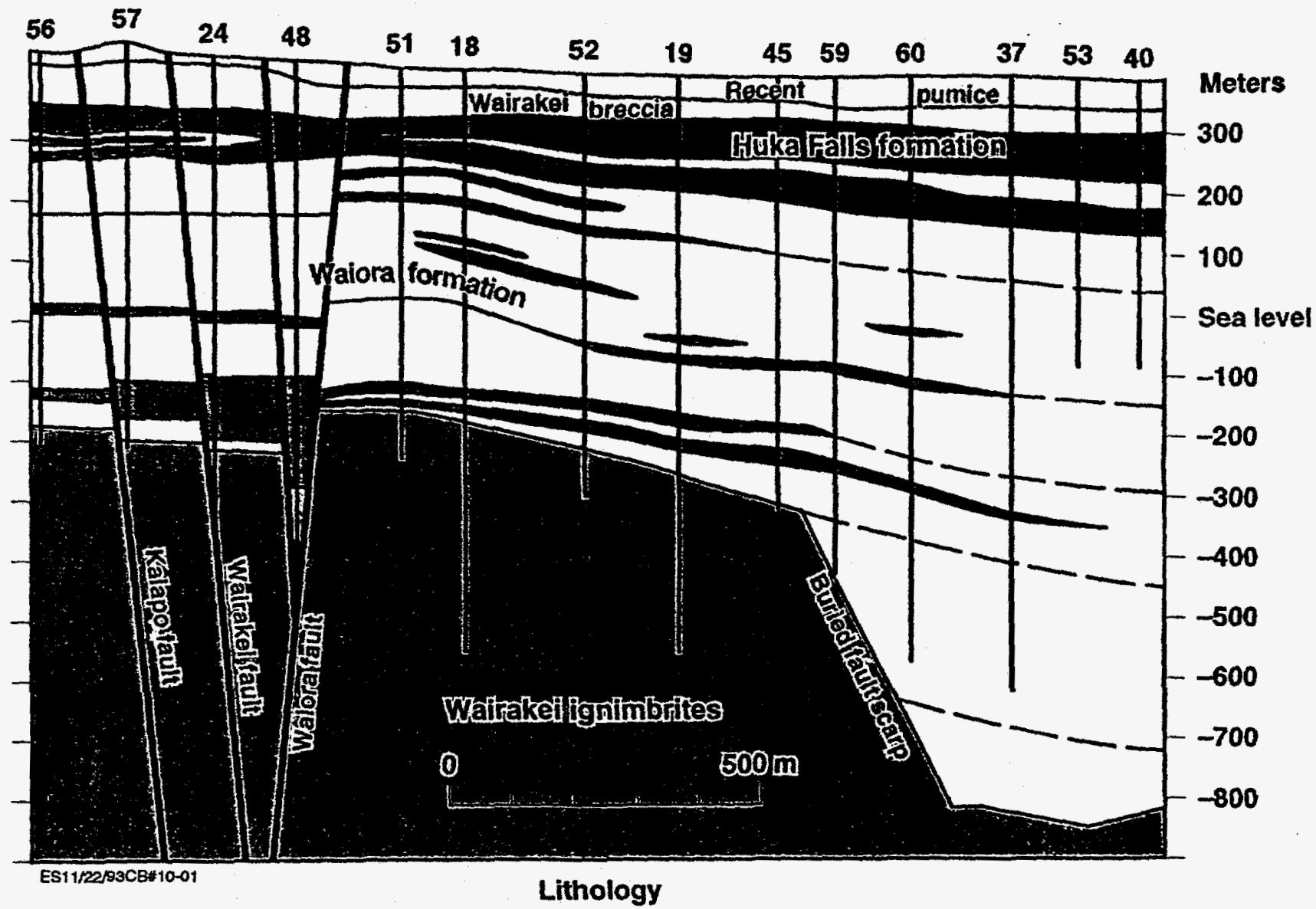

Ash showers and alluvium

Siltstone and pumiceous sandstone, diatomite

Pumice breccia, non-welded lapilli, crystal and vitric tuff

Waiora Valley andesite

Dark grey, vesicular, hypersthene andesites
Wairakei ignimbrites

Dense, green-grey, quartzose ignimbrite (welded crystal tuff)

Figure 3. Cross-section of part of the Wairakei borefield. Numbers indicate boreholes. From Grindley (1965). 

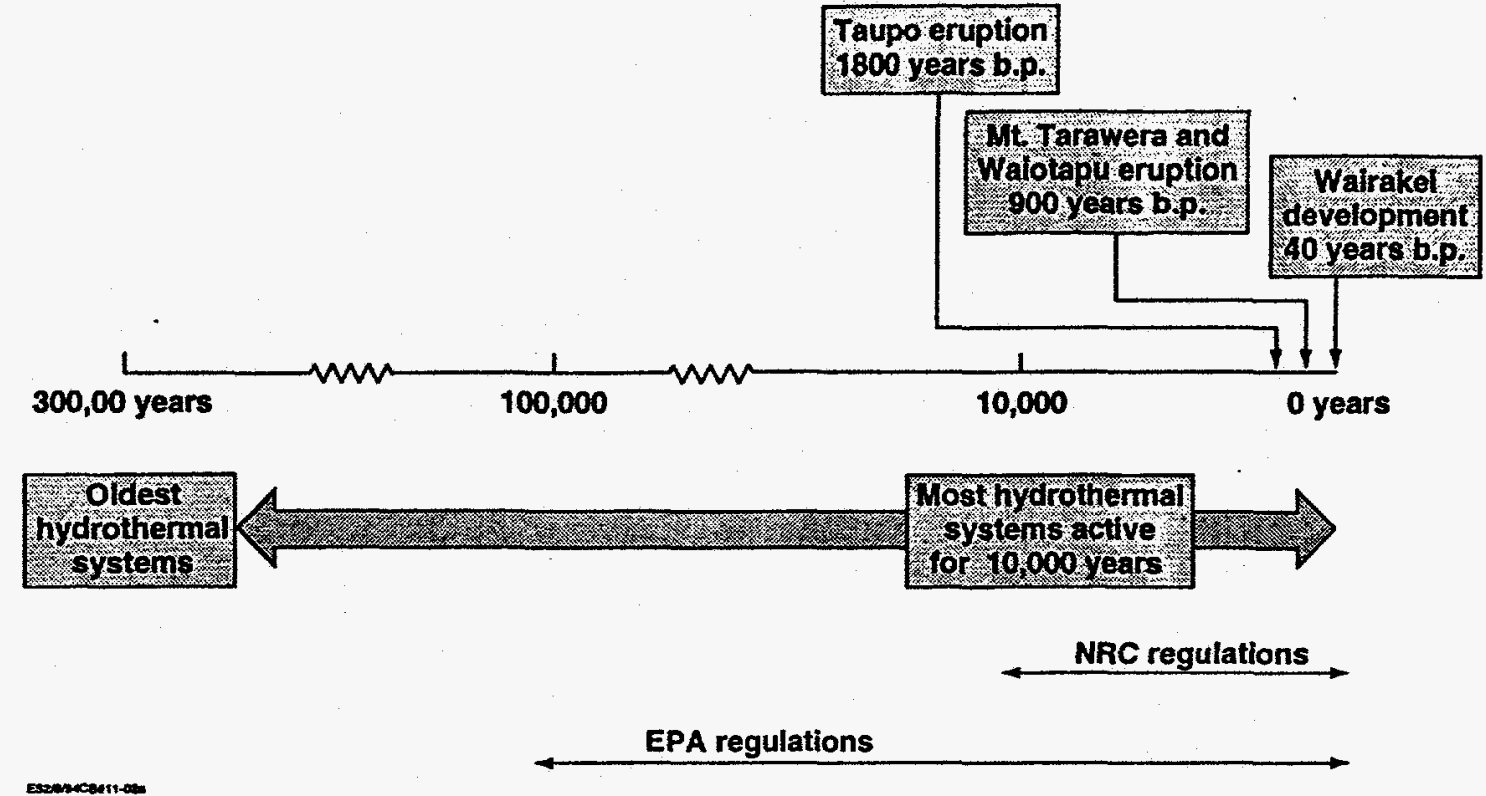

Figure 4. Time line comparing hydrothermal events in New Zealand to federal regulations proposed by the Nuclear Regulatory Commission (NRC, 1988) and the Environmental Protection Agency (EPA, 1985).

in the 1950's, and is continuing to the present day. Geothermal energy production also occurs at Broadlands/Ohaaki and Kawerau, among other sites.

Utilization of TVZ hydrothermal areas for geothermal power since 1953 has resulted in striking changes in the geothermal areas which we can use to test our ability to model and/or monitor and record the effects of shorter-term perturbations in natural systems. For example, fluid-dominated, water-saturated zones at Wairakei have turned into steam-dominated, unsaturated zones. The formation of a steam zone in the ignimbrites has resulted in mass transport of vast amounts of silica. The area is currently called "Craters of the Moon" because of the impact of the dissolution on topography.

Mineral-fluid-manufactured material interactions related to the Yucca Mountain near-field environment and altered zone

An important advantage to selecting exploited geothermal systems is that a variety of manmade materials are introduced into the areas during drilling and production. Manufactured materials, such as concretes and metals, are widely used for a variety of purpose in the production fields (called borefields). For example, various cement formulations have been widely used to construct silencers, cooling towers, and drain channels in borefields. Cements and metals have been used in drilling and production at the Wairakei geothermal field for over 40 years. These materials have been in contact with hot water and steam with a wide range of chemistries during this time. Figure $5 \mathrm{a}$ illustrates the degradation undergone by cement used in the Wairakei borefield. Figure $5 \mathrm{~b}$ illustrates the contrasting chemical environments in which concretes have been reacting.

TVZ geothermal fields provide excellent opportunities to evaluate the long-term mechanisms and rates of degradation of manufactured materials in contact with steam and hot water. The 


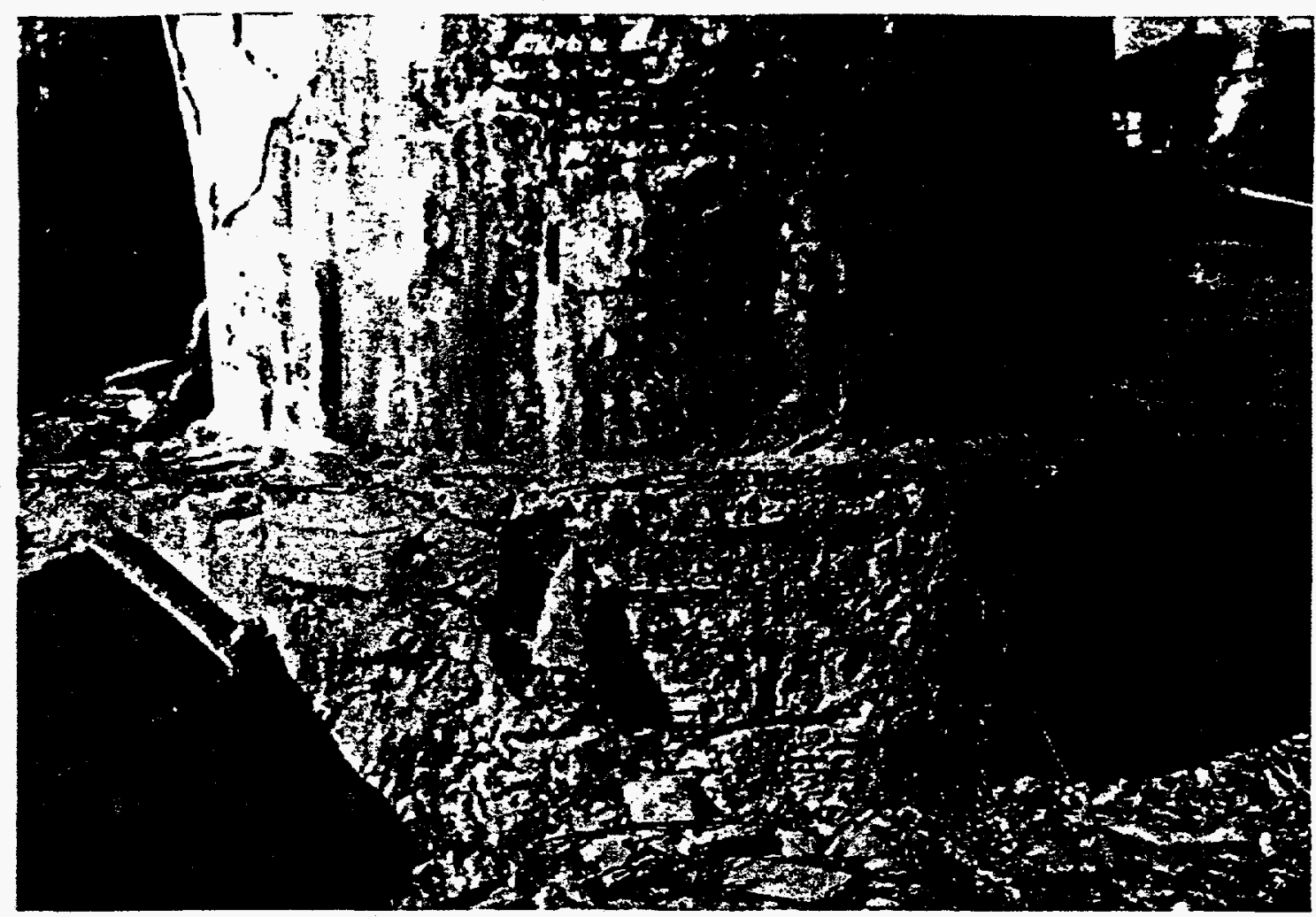

Figure 5a. Degradation of cement silencer in the Wairakei borefield.

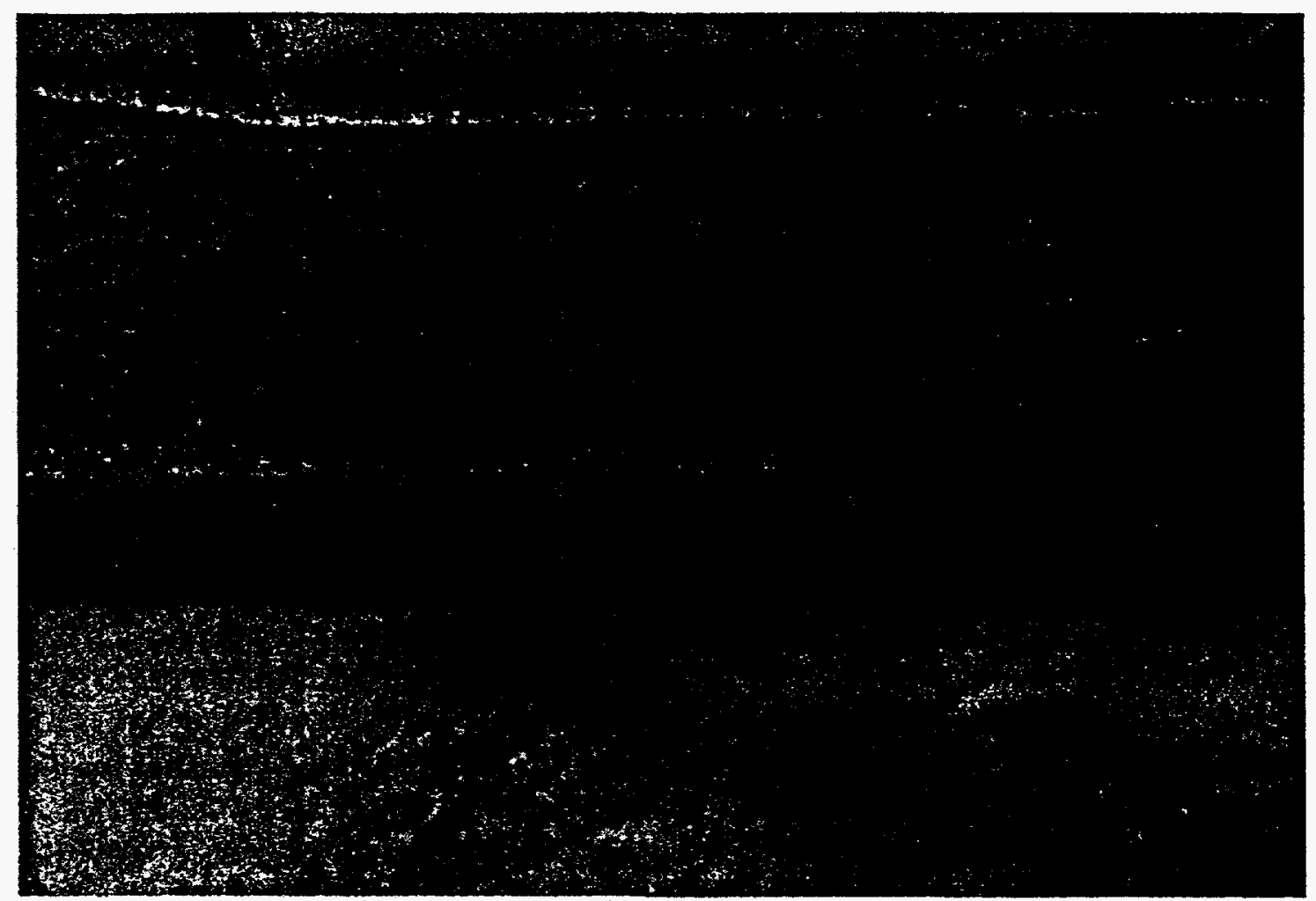

Figure 5b. Adjacent concrete channels, draining waters of different chemistry from the Wairakei borefield, exemplify historical analogue. Long-term cement degradation in the two channels are compared in a system for which water chemistry, original cement chemistry and duration of the reactions can be defined. 
interaction of manufactured materials with fluids at elevated temperature over tens of years will be characterized, evaluated and modeled. To date, we have obtained samples of these cements to determine their degradation owing to both biotic and abiotic factors (e.g. Rogers, 1993; 1994a,b,c; 1995). The study of complex chemical systems in which the normal evolution of microbes is allowed to occur enables us to assess the significance of microbially mediated versus abiotic chemical pathways.

Geochemical modeling codes can be applied to the degradation of introduced materials in a geological repository setting because of their ability to describe chemical processes over very long periods of time. However, application of the codes to introduced materials will require addressing the following concerns. First, the thermodynamic data bases must be expanded to include phases and species of importance when evaluating the impact of fabricated materials, but which are not presently in the EQ3/6 data base (Meike, 1994; Bruton et al., 1994b). Second, a particular area of concern is our ability to model the formation of colloids from materials such as metals and concrete, and the ability of modifications in water chemistry to alter the sorption characteristics of colloids (Meike and Wittwer, 1994). Third, microbially mediated reactions may be significant in the degradation of fabricated materials. The significance of biotic reactions relative to the abiotic reactions that $\mathrm{EQ} 3 / 6$ currently describes must be determined. Fourth, the degradation of organic compounds is not adequately addressed by the version of EQ3/6 currently certified for use in quality-affecting work (Meike et al., 1994a), although the problem is being addressed in the version under development.

The potential significance of sources of introduced water to the total water budget in the nearfield environment has not been addressed systematically as yet. Some sources such as cement may release water over time as a function of temperature and relative humidity (Meike et al., 1994b). Geothermal power sites offer the opportunity to assess our modeling capability in this area.

\section{Secondary mineralogy}

Figure 6 illustrates some of the major secondary minerals and their thermal stability ranges found in active hydrothermal systems in the TVZ. The minerals up to about $200^{\circ} \mathrm{C}$ are quite similar to those occurring in Yucca Mountain tuffs today owing to earlier hydrothermal activity associated with the Timber Mountain-Oasis Valley caldera complex over $10 \mathrm{~m}$.y. ago (Broxton, Bish and Warren, 1987). Secondary mordenite, clinoptilolite, stilbite and possibly dachiardite have been identified in more recent studies in lower temperature environments $\left(<150^{\circ} \mathrm{C}\right)$ (Reyes et al., 1994; see below). Mordenite, clinoptilolite and stilbite are prominent phases at Yucca Mountain, whereas dachiardite precipitated during hydrothermal testing of Yucca Mountain tuffs (e.g. Knauss et al., 1985, 1987).

\section{Relation of fluid-rock interactions in the TVZ to Yucca Mountain scenarios}

Buscheck and Nitao (1993) defined distinctive hydrothermal flow regimes expected in the Yucca Mountain post-emplacement environment as a result of their modeling with the V-TOUGH numerical simulator of coupled fluid, gas and heat transport in fractured, porous media. Many of the ongoing rock-fluid interaction processes in the TVZ are reminiscent of scenarios outlined by Buscheck and Nitao (1993) and Glassley et al. (1993). Study of New Zealand regimes analogous 


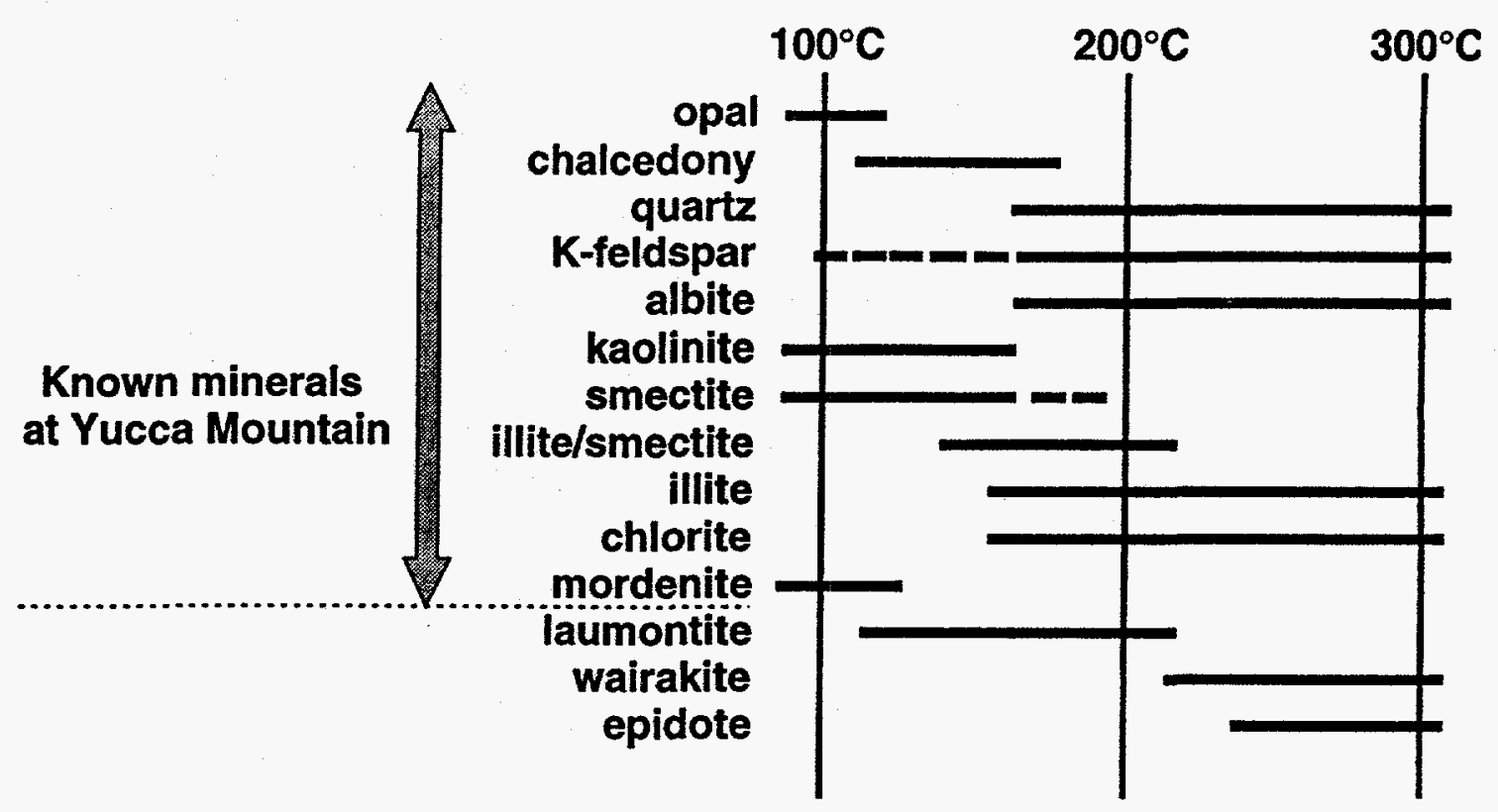

Figure 6. Secondary minerals and their thermal stability in New Zealand geothermal systems (modified from Simmons, Browne and Brathwaite, 1992). Alteration restricted to that caused by near-neutral chloride-rich waters.

to those anticipated at Yucca Mountain will aid us in forecasting changes in the near-field environment and altered zone.

Glassley et al. (1993) re-designated Buscheck and Nitao's regimes as A, B, C and D. The characteristics of each regime will be described briefly below. (For more detailed descriptions, see Glassley et al., 1993). A few exemplary selections of analogous characteristics of New Zealand systems will then be described.

Regime A is sub-boiling, but with evaporation taking place that will change the ambient relative humidity. Regime B is at the boiling point, and describes a zone in which water boils, is transported along fractures as steam until it recondenses and is either imbibed into the matrix or flows back to the boiling front again to repeat the process (sometimes called refluxing, or the condensate umbrella). Below the repository, however, condensed steam will merely flow downward along fractures. Regime $\mathrm{C}$ is above the ambient boiling point, and is generally dried-out except for limited masses of water held in small pores of the rock, or water that is trapped within the rock matrix. Finally, regime D represents areas where the temperature is lower than the boiling point, but that was once subjected to higher temperatures that altered the physical and chemical characteristics of the rock (Buscheck and Nitao, 1993; Glassley et al., 1993).

Most of the TVZ zones critiqued to date are fully fluid-saturated, and so are not appropriate for studies of the effects of relative humidity on fluid chemistry and mineralogy (e.g. regime A). However, large sections of the silicic rocks in the TVZ geothermal fields and hydrothermal areas are subjected to temperatures ranging from about 20 to $100^{\circ} \mathrm{C}$. Their mineralogic relations and fluid chemistry will be examined to determine the response of silicic volcanic rocks to elevated temperature. We will also test the extent to which we can describe fluid-mineral relations with $\mathrm{EQ} 3 / 6$ in systems with temperatures in the range of 20 to $100^{\circ} \mathrm{C}$. 
The geothermal systems in the TVZ contain many examples of the impact of boiling on fluid chemistry and mineralogy (e.g. regime B). For example, water at depth in the Wairakei geothermal field is below the boiling point. The water boils as it rises owing to the pressure drop during convective circulation. In much of the TVZ, however, a much smaller percentage of the water boils off than is anticipated in Yucca Mountain scenarios. Nonetheless, we can obtain evidence of the mineralogic response of systems (e.g. Kawerau) to repeated boiling events.

Interactions between fluids and rocks above $100^{\circ} \mathrm{C}$ representative of regime $\mathrm{C}$ characterize most TVZ geothermal areas, and many hydrothermal surface features. The tests of our geochemical modeling codes and data bases have begun with high temperature $\left(>200^{\circ} \mathrm{C}\right)$ systems in which equilibrium would be expected to dominate over kinetics.

The retrograde reactions and secondary mineral precipitation that might occur in regime $D$ will be examined in the TVZ as well. Reyes et al. (1994) described the mineralogic impact on incursion of cold waters into silicic rocks originally subjected to elevated temperatures. Lonker et al. (1990) also describe the mineralogic response to the descent of cooler fluids in the BroadlandsOhaaki field. This process is analogous to rapid infiltration, and will allow us to test our ability to simulate the effect of this process.

\section{Saturated systems: Appropriate analogues for Yucca Mountain?}

The New Zealand hydrothermal systems are mostly fluid-saturated, whereas the potential Yucca Mountain repository lies in the unsaturated zone. The hydrologic models of Buscheck and Nitao (1993) suggest that extensive portions of the volcanic sequence at Yucca Mountain will be at saturations greater than ambient over extended time periods as a result of boiling and condensation (Figure 7). Thermodynamic calculations suggest that the activity of water will be close to one in these regimes, indicating that chemical processes will occur as though the system is saturated (Bruton and Viani, 1992). Limitations in available water mass must still be taken into account. Nonetheless, the New Zealand systems are appropriate analogues for processes in the boiling, condensation and altered zones.

Our ability to determine the impact of fluid-rock-materials interactions depends to a large extent on our knowledge of the mechanisms by which such reactions take place. In systems characterized by high fluid-rock ratios, the dissolution-precipitation mechanisms are rather wellknown. Details of the physical processes of fluid-rock reaction in the presence of a vapor in the unsaturated zone are not well known, however. It is not clear whether the same mechanisms control reactions to a similar extent in low fluid-rock ratio systems as in high ratio systems, or whether additional factors come into play. We will use our experience in saturated systems as a baseline from which to develop a strategy to simulate unsaturated conditions. We will then be better able to identify the impact of saturation state when we investigate fluid-rock interactions in vapor-dominated systems.

\section{Collaborative relationships}

A collaborative relationship has been established among the LLNL Yucca Mountain Project Chemical and Mineralogical Changes in the Post-Emplacement Environment and Introduced Materials tasks and the Institute of Geological and Nuclear Sciences (IGNS) at the Wairakei Research Centre in Wairakei, New Zealand. IGNS has a research staff of chemists, geologists, and 
Liquid saturation

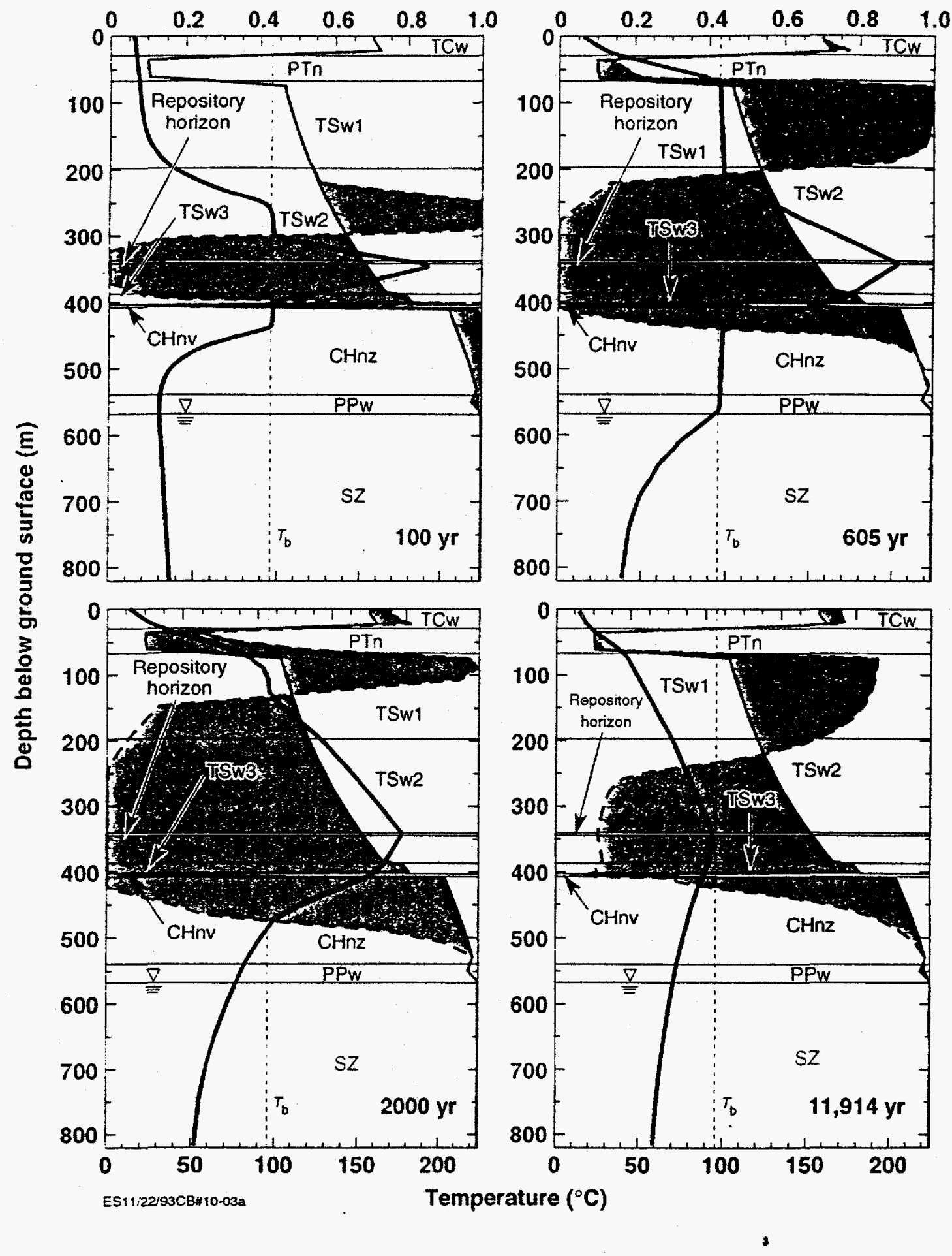

Figure 7. Liquid saturation (dashed line) and temperature (solid line) profiles along repository centerline calculated by Buscheck and Nitao (1993) for the potential Yucca Mountain repository. Ambient liquid saturation state traced by fine solid line. Blue highlights elevations with liquid saturation above ambient values; red highlights elevations below ambient saturation. Calculated assuming $30 \mathrm{yr}$-old spent nuclear fuel, an areal power density of $114 \mathrm{~kW} / \mathrm{acre}$, and a net recharge flux of $0 \mathrm{~mm} / \mathrm{yr}$. Hydrothermal flow in the saturated zone taken into account. Figure from Buscheck and Nitao (1993). 
geophysicists who have many years of experience working in the TVZ. Their experience includes sampling and analysis of fluid and rock samples from a range of environments, and a record of publishing the results of such work in refereed international scientific journals. The lead investigator and our main contact at IGNS is Dr. Bruce Christenson, Group Leader of the Geothermal Group.

The Wairakei Research Centre possesses a wide range of state-of-the-art analytical and research facilities to allow rapid analysis of fluids and solids. They are specialists in the collection and analysis of geothermal fluids, and have decades of records of past analyses, as well collections of previously collected fluids. The Wairakei Research Centre is located in the TVZ, which will reduce time between sample collection and analysis to obtain better fluid analyses. It will also facilitate sample collection and on-site monitoring of field experiments. Several planned research projects will require regular monitoring of field experiments set up close to Wairakei (see below).

\section{LLNL/IGNS Accomplishments to Date}

Work in FY1994 by the Institute of Geological and Nuclear Sciences funded by LLNL focused on: 1) obtaining data on mineral relations and fluid chemistry required to test the EQ3/6 code and its thermodynamic data base GEMBOCHS; 2) identifying natural thermal features with a variety of physical and chemical conditions in which to test dissolution/corrosion rates; 3 ) collecting and analyzing field data on rates of silica precipitation from heated fluids; and 4) characterizing the microbially influenced degradation of concrete in the Broadlands/Ohaaki cooling tower.

Four quarterly reports were submitted by IGNS to LLNL regarding the mineral relations and fluid chemistry in the Wairakei and Kawerau geothermal fields (Reyes et al., 1993a,b; 1994a,b). Information in these reports was used in the initial code tests described in Bruton et al. (1994). One IGNS quarterly report (Mroczek, 1994) summarized available field and laboratory data on silica precipitation rates, with recommendations for further studies. Information from this report is currently being used to plan an LLNL experimental program that will complement the IGNS field studies and experiments.

Five progress reports on the concrete degradation problem were submitted to LLNL from a subcontractor under contract to LLNL (Rogers, 1993; 1994a,b,c; 1995).

\section{Projects planned for FY1995/1996}

The following project summaries describe planned joint LLNL/IGNS activities for FY1995 and 1996.

1. Measure and evaluate rates of solid dissolution/corrosion in thermal features. IGNS and LLNL will locate thermal features in which to suspend samples of minerals, rocks, metals and cementitious materials. After emplacement, IGNS will be responsible for periodic analyses of water chemistry and weight loss measurements on mineral and rock samples. IGNS will remove metal and cement samples periodically and send to LLNL for analysis. SEM and other analytical techniques may be applied as necessary to characterize the dissolution process. The goals of this task are to: 1) observe mechanisms, rates and products of degradation of manufactured materials 
in varying fluid chemistries and physical conditions; 2) measure dissolution rates of minerals in varying fluid chemistries and physical conditions; 3) derive required constants in kinetic equations describing mineral dissolution; and 4) compare derived constants to laboratory-derived constants.

2. Determine rates and controls of silica precipitation from heated fluids. IGNS will work with LLNL to design and conduct experiments in which rates of silica precipitation are determined in natural, field and laboratory settings. The work will result in information about the chemical and physical factors controlling silica precipitation rates, and identification of a kinetic rate equation for silica precipitation with associated rate equation parameters. This equation can then be used in coupled hydrology/geochemistry codes being used to evaluate conditions in the post-emplacement environment.

3. Evaluate fluid mixing and mineral-fluid equilibria at elevated temperature in geothermal fields. IGNS will identify physical and chemical phenomena resulting in changes in fluid chemistry and alteration mineralogy. Potential examples include fluid-mixing scenarios in the Kawerau geothermal field involving mixing of deep alkaline fluids with cold meteoric water, steam condensate and oxidized steam-heated water. IGNS will collect data on fluid chemistry and mineralogy in such environments. IGNS will also continue to collect additional data as required in the Wairakei and Kawerau geothermal fields to support ongoing fluid-mineral equilibria calculations. Acquired data will be used to test EQ6 simulations of the processes and their impact on fluid chemistry and alteration mineralogy.

4. Measure the naturally occurring actinide-series isotopes in geothermal rocks and fluids as a function of temperature, lithology, water chemistry and colloid content. These data will constrain the rates and mechanisms of geochemical reactions and transport processes. IGNS and LLNL will jointly identify existing data sources concerning the occurrence and distribution of naturally occurring actinide and rare earth elements in New Zealand hydrothermal systems. Fluid and rock samples will be collected from a variety of chemical and thermal environments for analytical determination of naturally occurring actinide and rare earth elements. This work will focus initially on U-Th disequilibrium studies. Data will be used to evaluate the transport of radionuclides in repository-type environments.

5. Evaluate microbially influenced degradation of concrete composing the Broadlands/ Ohaaki cooling tower. Samples will be sent to LLNL and its subcontractors for further study. IGNS will aid LLNL in identifying and obtaining degraded construction materials and water samples at geothermal power sites that have been exposed to hot water and steam of known compositions for known periods of time. These samples will be analyzed by LLNL to identify types, mechanisms and extent of degradation as a function of the physical and chemical environment. Microbes isolated from these environments will be used in follow-up laboratory studies. Results will be used to assess the need to add an auxiliary microbial module to the EQ3/6 code in order to model material degradation. 


\section{Conclusions}

The hydrothermal areas of TVZ provide unparalleled opportunities to test geochemical models and observe the impact of repository processes on environments similar to those envisioned at Yucca Mountain. The New Zealand geothermal systems are well-characterized with a rock type (silicic volcanics) and temperature range $\left(10-<300^{\circ} \mathrm{C}\right)$ overlapping those of Yucca Mountain scenarios. They possess a wide variety of scenarios for study over a range of chemical and physical conditions and spatial scales. Furthermore, many of the chemical processes in the hydrothermal systems have been operating for periods of time spanning the time scales important in repository models. Opportunities exist to examine a variety of manufactured materials-fluid-rock interactions. Much of the required information is already available, which is both cost- and time-effective. Finally, we can tap the expertise of researchers who have worked in this area for years.

Work in FY1994 by the Institute of Geological and Nuclear Sciences funded by LLNL focused on: 1) obtaining data on mineral relations and fluid chemistry required to test the EQ3/6 code and its thermodynamic data base; 2 ) identifying natural thermal features with a variety of physical and chemical conditions in which to test laboratory-derived vs. field-based dissolution/ corrosion rates; and 3) collecting and analyzing field data on rates of silica precipitation from heated fluids.

Projects for FY1995 and 1996 include: 1) determining rates and mechanisms of dissolution/ corrosion of minerals, rocks, metals and cementitious materials in natural thermal features to characterize their behavior in the repository environment; 2) determining precipitation rates of silica which can be used in coupled hydrology/geochemistry codes to predict permeability variations in the post-emplacement environment; 3) test the ability of EQ3/6 and the adequacy of its thermodynamic data base to predict changes in mineralogy and fluid chemistry in the postemplacement environment; and 4) determine the distribution of naturally occurring actinideseries isotopes in silicic volcanic rocks subjected to fluid flow at elevated temperature in order to better evaluate potential radionuclide transport at Yucca Mountain. 


\section{References}

Broxton, D.E., Bish, D.L. and Warren, R.G., 1987, Distribution and chemistry of diagenetic minerals at Yucca Mountain, Nye County, Nevada: Clays and Clay Min., v. 35, no. 2, p. 89-110.

Bruton, C.J., Phillips, B.L., Meike, A., Martin, S. and Viani, B.E., 1994a, Cement minerals at elevated temperature: Thermodynamics and structural characteristics: Mat. Res. Soc. Symp. Proc. v. 333, p. 327-333.

Bruton, C.J., Glassley, W.E., Bourcier, W.L., 1994b, Field-based tests of geochemical modeling codes using New Zealand hydrothermal systems: Lawrence Livermore National Laboratory Report UCRL-ID-118009.

Bruton, C.J. and Viani, B.E., 1992, Geochemical modeling of water-rock interactions in the unsaturated zone. In Water-Rock Interaction 7, ed. by Y.K. Kharaka and A.S. Maest (A.A. Balkema, Netherlands, 1992), p. 705-708.

Buscheck, T.A. and Nitao, J.J., 1993, Repository-heat-driven hydrothermal flow at Yucca Mountain, Part I: Modeling and analysis: Nuclear Tech., v. 104, p. 418-448.

Chapman, N., Cloke, P.L., Petit, J-C., Smellie, J.A.T., van Luik, A.E.J., 1992, Applications of natural analogue studies to Yucca Mountain as a potential high level radioactive waste repository: Natural Analogue Review Group, U.S. Dept. of Energy, unpublished manuscript.

DOE (Dept. of Energy), 1988, Site Characterization Plan: U.S. Dept. of Energy DOE/RW0199, v. VII, Part B.

EPA (Environmental Protection Agency), 1985, Environmental standards for the management and disposal of spent nuclear fuel, high-level and transuranic wastes: Final rule: U.S. Code of Federal Regulations, 40 CFR Part 191, Washington, D.C.

Glassley, W.E., Bruton, C.J. and Bourcier, W.L., 1993, Testing long-term predictions from hydro-geochemical models: Mat. Res. Soc. Symp. Proc. v. 333, p. 805-810.

Grindley, G.W., 1965, The geology, structure, and exploitation of the Wairakei geothermal field, Taupo, New Zealand: New Zealand Geol. Surv. Bull. 75, New Zealand Dept. Sci. Industrial Res.

Knauss, K.G., Beiriger, W.J., Peifer, D.W. and Piwinskii, A.J., 1985, Hydrothermal interaction of solid wafers of Topopah Spring Tuff with J-13 water and distilled water at 90,150 , and $250^{\circ} \mathrm{C}$, using Dickson-type, gold-bag rocking autoclaves: Lawrence Livermore National Laboratory Report UCRL-53645.

Knauss, K.G., Beiriger, W.J. and Peifer, D.W., 1987, Hydrothermal interaction of solid wafers of Topopah Spring Tuff with J-13 water at 90 and $150^{\circ} \mathrm{C}$ using Dickson-type, gold-bag rocking autoclaves: Long-term experiments: Lawrence Livermore National Laboratory Report UCRL-53722. 
Lonker, S.W., Fitzgerald, J.D., Hedenquist, J.W., and Walshe, J.L., 1990, Mineral-fluid interactions in the Broadlands-Ohaaki geothermal system, New Zealand: Am. J. Sci., v. 290, p. 9951068.

Meijer, A., Investigations of natural geologic and geochemical analogs in relation to a potential nuclear waste repository at Yucca Mountain, Nevada: unpublished manuscript.

Meike, A., 1994, Chemical implications for the presence of introduced materials in the postemplacement environment: Mat. Res. Soc. Symp. Proc. v. 333, p. 835-839.

Meike, A. and Wittwer, C., 1994, Introduced materials and colloid formation: A report on the current state of knowledge: Mat. Res. Soc. Symp. Proc. v. 333, p. 783-789.

Meike, A., Bourcier, W.L., Alai, M., Haldeman, D.L., Amy, P.S., Lagadinos, T. and Hersman, L., 1994a, Potential long-term chemical effects of diesel fuel emissions on a mining environment: Yucca Mountain Project MOL73, September 30, 1994.

Meike, A., Onofrei, M., Bruton, C.J. and Viani, B.E., 1994b, Progress in understanding the structure and thermodynamics of calcium silicate hydrates: 5th Ann. Intl. High Level Rad. Waste Mgmt. Proc., Las Vegas, Nevada, May, 1994.

Mroczek, E.K., 1994, Review of silica deposition rates at Ohaaki, Rotokawa and Wairakei geothermal fields and comparison of observed rates with predicted deposition rates calculated using three different kinetic deposition models: Inst. of Geol. and Nuclear Sciences Proprietary Report 722305.15, September, 1994.

NRC (Nuclear Regulatory Commission), 1988, Disposal of high-level radioactive wastes in geologic repositories: Licensing procedures: Code of Federal Regulations, Energy, Title 10, Part 60 , Washington, D.C.

Reyes, A.G., Giggenbach, W.F. and Christenson, B.W., 1993a, First report of the EQ3-EQ6 code validation contract: Inst. of Geol. and Nuclear Sciences Proprietary Report 722305.15A.

Reyes, A.G., Christenson, B.W. and Giggenbach, W.F., 1993b, Second report of the EQ3EQ6 code validation contract: Inst. of Geol. and Nuclear Sciences Proprietary Report 722305.15B, December, 1993.

Reyes, A.G., Giggenbach, W.F. and Christenson, B.W., 1994a, Third report of the EQ3-EQ6 code validation contract: Inst. of Geol. and Nuclear Sciences Proprietary Report 724305.15C, October, 1994.

Reyes, A.G. and Christenson, B.W., 1994b, Fourth report of the EQ3-EQ6 code validation contract: Inst. of Geol. and Nuclear Sciences Proprietary Report 724305.15D, December, 1994.

Rogers, R.D., 1993, Assessment of the effects of microbially influenced degradation on a massive concrete structure: Biodegradation Systems, Inc. Report, Dec. 1993. 
Rogers, R.D., 1994a, Assessment of the effects of microbially influenced degradation on a massive concrete structure: Report 1: Biodegradation Systems, Inc., June 1994.

Rogers, R.D., 1994b, Analysis report: Results of examination of selected New Zealand samples by electron microscopy: Biodegradation Systems, Inc. Report, Dec. 1994.

Rogers, R.D., 1994c, Interim progress report: Test report 1.e: Results of accelerated mid testing on Yucca Mountain concrete types $\mathrm{H}$ and $\mathrm{K}$ : Biodegradation Systems, Inc. Report Dec. 13, 1994.

Rogers, R.D., 1995, Assessment of the effects of microbially influenced degradation on a massive concrete structure: Report 3: Biodegradation Systems, Inc., Jan. 9, 1995.

Simmons, S.F., Browne, P.R.L. and Brathwaite, R.L., 1992, Active and extinct hydrothermal systems of the North Island, New Zealand: Soc. Econ. Geol. Guidebook Series Vol. 15, Citizen Printing Co., Fort Collins, CO.

Wilder, D.G., 1993, Preliminary near-field environment report. Volume II: Scientific overview of near-field environment and phenomena: Lawrence Livermore National Laboratory Report UCRL-LR-107476 Vol. 2.

Wolery, T.J., Jackson, K.J., Bourcier, W.L., Bruton, C.J., Viani, B.E., Knauss, K.G. and Delany, J.M., 1990, Current status of the EQ3/6 software package for geochemical modeling. In D.C. Melchior and R.L. Bassett (eds.), Chemical Modeling of Aqueous Systems II. American Chemical Society, Washington, D.C. 